\title{
Targeted deletion of miR-132/-212 impairs memory and alters the hippocampal transcriptome
}

\author{
Katelin F. Hansen, ${ }^{1}$ Kensuke Sakamoto, ${ }^{1}$ Sydney Aten, ${ }^{1}$ Kaiden H. Price, ${ }^{1}$ \\ Jacob Loeser, ${ }^{1}$ Andrea M. Hesse, ${ }^{1}$ Chloe E. Page, ${ }^{1}$ Carl Pelz, ${ }^{2}$ J. Simon C. Arthur, ${ }^{3}$ \\ Soren Impey, ${ }^{2}$ and Karl Obrietan ${ }^{1}$
}

${ }^{1}$ Department of Neuroscience, Ohio State University, Columbus, Ohio 43210, USA; ${ }^{2}$ Oregon Stem Cell Center, Oregon Health and Science University, Portland, Oregon 97239, USA; ${ }^{3}$ College of Life Sciences, University of Dundee, Dundee DD1 SEH, United Kingdom

miR-132 and miR-212 are structurally related microRNAs that have been found to exert powerful modulatory effects within the central nervous system (CNS). Notably, these microRNAs are tandomly processed from the same noncoding transcript, and share a common seed sequence: thus it has been difficult to assess the distinct contribution of each microRNA to gene expression within the CNS. Here, we employed a combination of conditional knockout and transgenic mouse models to examine the contribution of the miR-132/-212 gene locus to learning and memory, and then to assess the distinct effects that each microRNA has on hippocampal gene expression. Using a conditional deletion approach, we show that miR132/-212 double-knockout mice exhibit significant cognitive deficits in spatial memory, recognition memory, and in tests of novel object recognition. Next, we utilized transgenic miR-132 and miR-212 overexpression mouse lines and the miR132/-212 double-knockout line to explore the distinct effects of these two miRNAs on the transcriptional profile of the hippocampus. Illumina sequencing revealed that miR-132/-212 deletion increased the expression of 1138 genes; Venn analysis showed that 96 of these genes were also downregulated in mice overexpressing miR-132. Of the 58 genes that were decreased in animals overexpressing miR-212, only four of them were also increased in the knockout line. Functional gene ontology analysis of downregulated genes revealed significant enrichment of genes related to synaptic transmission, neuronal proliferation, and morphogenesis, processes known for their roles in learning, and memory formation. These data, coupled with previous studies, firmly establish a role for the miR-132/-212 gene locus as a key regulator of cognitive capacity. Further, although miR-132 and miR-212 share a seed sequence, these data indicate that these miRNAs do not exhibit strongly overlapping mRNA targeting profiles, thus indicating that these two genes may function in a complex, nonredundant manner to shape the transcriptional profile of the CNS. The dysregulation of miR-132/-212 expression could contribute to signaling mechanisms that are involved in an array of cognitive disorders.

[Supplemental material is available for this article.]

microRNAs (miRNAs) are small (approximately 22 nucleotides) noncoding regulatory RNA molecules that contribute to the posttranscriptional repression of target mRNAs. miRNAs are believed to target over $60 \%$ of the genome and are expressed in a timeand tissue-specific manner (Lagos-Quintana et al. 2002; Giraldez et al. 2005; Friedman et al. 2009), including miRNA that are specifically expressed within the central nervous system (CNS; Kim et al. 2004; Packer et al. 2008). Disruption of miRNA processing leads to decreased brain size, aberrant axonal path finding, and early post-natal death (Cuellar et al. 2008; Davis et al. 2008). In addition, miRNAs play an important role in CNS development and cognitive function (Lim et al. 2005). A variety of behavioral learning tasks alter miRNA expression (Kye et al. 2011; Lin et al. 2011), and multiple miRNAs have been identified that regulate neuronal morphogenesis (Schratt et al. 2006; Abdelmohsen et al. 2010; Gao et al. 2010a; Cohen et al. 2011; van Spronsen et al. 2013; Li et al. 2014; Luhur et al. 2014).

Among these cognition-associated miRNAs are miR-132 and miR-212 (for review, see Wanet et al. 2012). These miRNAs are transcribed into the same pri-miRNA. Both miRNAs are down-

\section{Corresponding author: obrietan.1@osu.edu}

Article is online at http://www.learnmem.org/cgi/doi/10.1101//m.039578. 115 . stream of CRE sites and are under the control of the CREB/CRE transcriptional pathway; thus, both miRNAs exhibit inducible expression following neuronal activation (Vo et al. 2005). Deletion of these miRNA dramatically alters dendritic morphology (Magill et al. 2010), and miR-132 has additionally been shown to alter morphogenesis after expression both in culture and in vivo (Vo et al. 2005; Hansen et al. 2010; Mellios et al. 2011). miR-132 regulates dendritic morphogenesis by Rac1-PAK signaling via p250GAP, which in turn affects synaptic plasticity (Wayman et al. 2008; Impey et al. 2010; Lambert et al. 2010; Dhar et al. 2014; Lesiak et al. 2014). miR-132 has also been shown to be localized to axons and to regulate their extension via Rasa1 and p250GAP (Hancock et al. 2014; Marler et al. 2014). Deletion of the miR-132/-212 locus enhanced theta burst long-term potentiation (LTP), whereas overexpression of miR-132 in cultured hippocampal neurons limits synaptic depression following a train

(C) 2016 Hansen et al. This article is distributed exclusively by Cold Spring Harbor Laboratory Press for the first 12 months after the full-issue publication date (see http://learnmem.cshlp.org/site/misc/terms.xhtml). After 12 months, it is available under a Creative Commons License (AttributionNonCommercial 4.0 International), as described at http://creativecommons. org/licenses/by-nc/4.0/. 
of stimuli while increasing the paired-pulse ratio (Lambert et al. 2010; Remenyi et al. 2013).

Given these observations, there is keen interest in furthering our understanding the role of miR-132/-212 in activity-dependent synaptic plasticity and hippocampal-dependent learning and memory. To date, a number of studies have shown that both miRNAs are associated with impaired cognition when their expression levels are not maintained within a tightly regulated range (Scott et al. 2012; Wang et al. 2013; Kempf et al. 2014). Moreover, while moderate overexpression (approximately fivefold increase) of miR-132 impairs learning and memory, small increases $(\sim 1.5$-fold) serve to facilitate performance on memoryassociated behavior tasks (Hansen et al. 2013). This suggests that there exists an optimized level of miR-132 expression that can facilitate cognition, but that deviation from this range impairs neuronal function (Mellios et al. 2011; Tognini et al. 2011; Tognini and Pizzorusso 2012; Hansen et al. 2013).

Here, we use a conditional knockout system to selectively delete the miR-132/-212 locus from excitatory forebrain neurons to identify the cognitive deficits associated with miR-132/-212 deletion. In addition, we employ high-throughput RNA sequencing (RNA-seq) to profile the hippocampal transcriptomes of animals overexpressing miR-132 and miR-212, as well as of those with the conditionally deleted locus. By comparing these datasets we were able to narrow the pool of predicted miR-132/-212 targets and to identify a number of promising putative targets for screening. These data also provide insight into the overlapping and differential contributions of these miRNAs in the cluster, suggesting that each plays a specific and distinct functional role within the CNS, even while regulating some complementary targets. These data suggest that while miR-132 and miR-212 share identical seed regions, their divergence from one another across the rest of their sequence has a significant effect on mRNA targeting, further honing the regulatory capacity of this gene cluster.

\section{Results}

\section{Conditional deletion of $\mathrm{miR}-132 /-212$}

To explore the functional effects of miR-132/-212 deletion within the adult hippocampus, we employed a cre/lox strategy to target the miR-132/-212 locus for excision. The design of the targeting vector and the validation of homologous recombination were recently described (Remenyi et al. 2013). To delete the miR$132 /-212$ locus specifically in excitatory cell populations of the forebrain, the conditional miR-132/-212 mouse line was crossed with a well-characterized Cre recombinase line driven by the CaMKII promoter (Fig. 1A,B; Tsien et al. 1996). To validate the effective targeting of CRE recombinase to forebrain neurons, the CaMKII-Cre mice were crossed to a ROSA $26 \beta$-galactosidase reporter line (Soriano 1999) and tissue was immunolabeled for the expression of the $\beta$-galactosidase reporter. As expected, $\beta$-galactosidase expression was detected in forebrain regions, including the cortex, hippocampus, and amygdala (Fig. 1C, and data not shown). Next, tissue from the CaMKII-Cre::miR-132/-212 $2^{\mathrm{f} / \mathrm{f}}$ (conditional knockout: $\mathrm{cKO}$ ) mice was probed via in situ hybridization against miR-132. Representative data in Figure 1D reveals a loss of miR-132 expression in excitatory within the CA1 cell layer of the hippocampus. Together these data indicate that the conditional deletion approach is leading to a loss of miR-132 within excitatory pyramidal neurons. Finally, our conditional miR$132 /-212$ mice were generated in the expected Mendelian ratios; developmental deficits were not detected and the gross morphology of the brain did not appear to be affected (unpublished observation; Remenyi et al. 2013).

\section{Cognitive impairment following targeted deletion of $\mathrm{miR}-132 /-212$}

Having previously demonstrated learning and memory deficits following transgenic over expression of miR-132, we next sought
A

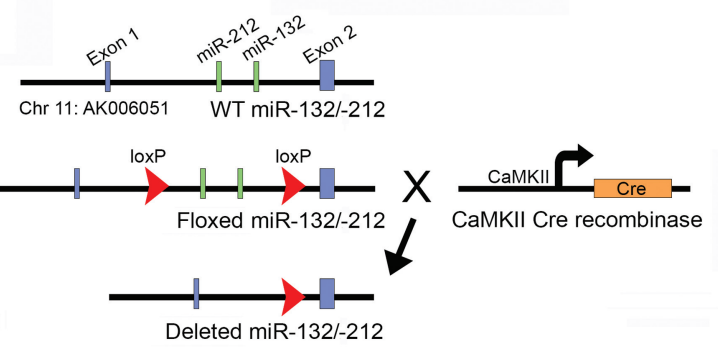

C

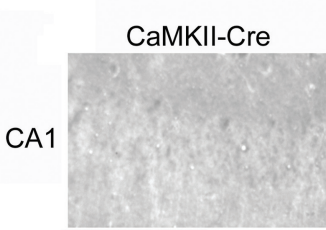

$\alpha-\beta-G a l$
CaMKII-Cre:: ROSA26 $\beta$-Gal

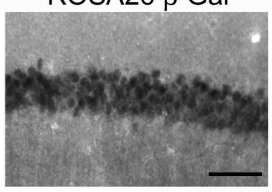

D

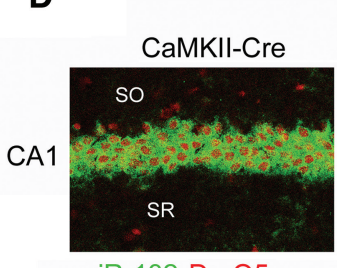

B

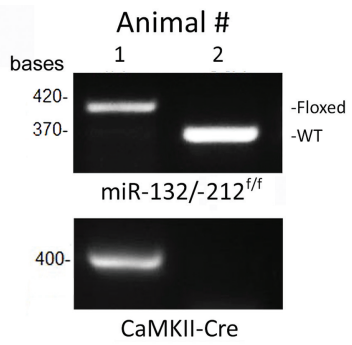

CaMKII-Cre:: $\mathrm{miR}-132 /-212^{\mathrm{f} / \mathrm{f}}$

Figure 1. Conditional deletion of miR-132/-212 in excitatory forebrain neurons. $(A)$ miR-132/-212 $2^{f / f}$ animals were crossed with a line expressing Cre recombinase driven by a CaMKII promoter to yield mice with miR-132/-212 selectively knocked out in forebrain neurons (CaMKII-Cre::miR-132/-212 $2^{\mathrm{f} f \mathrm{f}}$. (B) The addition of loxP sites in the CaMKII-Cre::miR-132/-212 f/f line was confirmed by PCR amplification of the miR-132/-212 locus. Similarly, the presence of the CamKII-Cre driver was identified by PCR. Animal 1 represents a conditional knockout animal with both the CaMKII-Cre driver and the miR-132/-212 locus with flanking loxP sites. In contrast, Animal 2 is negative for the CaMKII-Cre driver and is positive for wild-type (WT) miR-132/-212. (C) Effective CRE recombinase excision within hippocampal neurons was confirmed by crossing CaMKII-Cre mice to a ROSA 26 $\beta$-galactosidase reporter line. $\beta$-Galactosidase expression was detected in forebrain regions, including the CA1 cell layer of the hippocampus (scale bar $=40 \mu \mathrm{m}) .(D)$ Deletion of the miR-132/-212 locus was confirmed by fluorescent in situ hybridization within the CA1 cell layer. SR: stratium radiatum; SO: stratum oriens. Scale bar $=40 \mu \mathrm{m}$. 
to determine the cognitive effects of deleting this locus from excitatory neurons within the forebrain in cKO mice. We first examined recall memory using a novel object recognition task (Fig. 2A). Animals freely explored two identical objects and, after a 30-min delay period, animals were returned to the arena with one of the objects replaced with a new item. cKO animals exhibited an impaired capacity to recognize the familiar object, compared to control littermates without the CaMKII-Cre driver, which preferentially explored the novel object. cKO animals also demonstrated impairment on spatial memory tasks, such as contextual fear conditioning (Fig. 2B). Animals were allowed to explore a novel environment that was subsequently paired with a mild shock stimulus. When returned to the arena $24 \mathrm{~h}$ later, cKO animals exhibited a reduced fear response relative to control littermates as measured by freezing behavior. Spatial memory was also tested using the Barnes Maze (Fig. 2C,D). Animals were trained to locate an escape box among 20 equally spaced holes around the periphery of an elevated circular platform. While all animals demonstrated the ability to escape into the box and to improve their performance over time, cKO animals exhibited higher latencies to escape (Fig. 2C), and made more errors before escape (Fig. 2D), suggesting impaired capacity to form or retrieve spatial memories.

\section{High-throughput RNA-sequencing of the hippocampal transcriptome after altered miR-132/-212 expression}

One of the challenges of miRNA research is in identifying novel bone fide mRNA targets of miRNA regulation. Current informatic approaches rely on algorithmic prediction of targets based on seed-region base paring, melting temperatures, and other related parameters. While these approaches go a long way in predicting miRNA targets, they nevertheless yield a cumbersome number of false-positives. In an attempt to narrow the pool of putative mRNA targets that may be responsible for the cognitive deficits described here, we employed a high-throughput RNA-sequencing

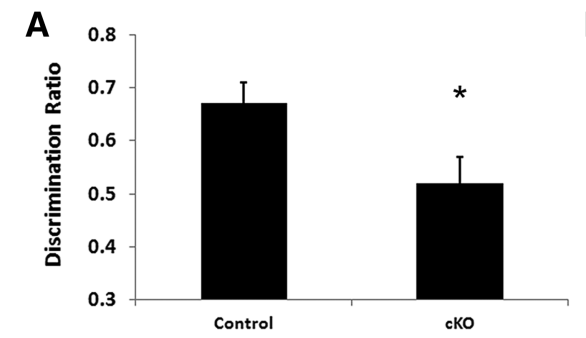

B

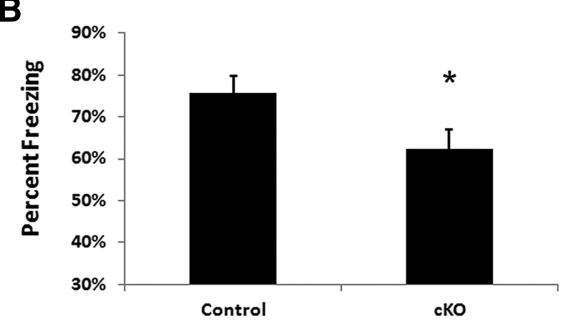

C

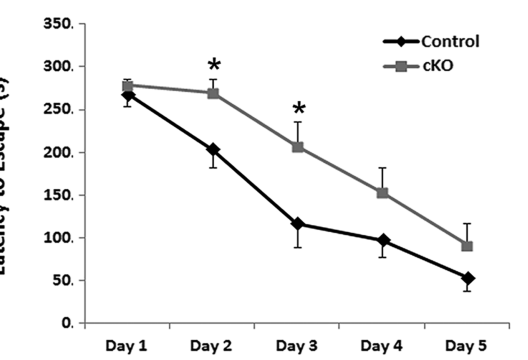

D

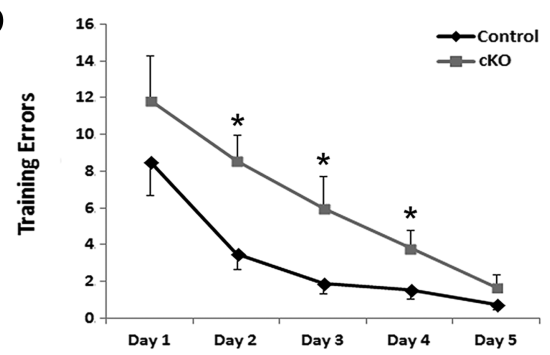

Figure 2. Deletion of miR-132/-212 within hippocampal excitatory neurons impairs learning and memory. (A) miR-132/-212 conditional knockout (CKO) animals exhibited impaired recognition memory on the novel object recognition task. Discrimination ratio $=$ (exploration time with novel object)/(total exploration time). Data are presented as mean \pm SEM, $n=14 /$ group, $\left(^{*}\right) P<0.05$. (B) CKO animals showed a significant decreases in freezing behavior after contextual fear conditioning compared to control mice. Data presented as mean \pm SEM, $n=14 /$ group, $\left({ }^{*}\right) P<0.05$. CKO animals also demonstrated impaired spatial learning capacity with increases in both latency to escape $(C)$ and training errors $(D)$ compared to controls. $n=13 /$ group, Latency: $F_{(1,24)}=5.44, P=0.028$, Error: $F_{(1,24)}=$ 7.32, $P<0.012)$. strategy to identify how the disruption of miR-132/-212 expression affected gene expression within the hippocampus (Fig. 3A). addition, to gain an even greater level of insight into the roles of these miRNAs in sculpting the gene expression in the hippocampus, we also performed high-throughput RNA-seq in mice that transgenically overexpress either miR-132 (Descried in Hansen et al. 2010, 2013) or a newly generated miR-212 transgenmouse line (Figs. 3B, 4). For both the miR-132 and mir-212 transgenic mouse lines, expression of the miR construct was driven by a tetracycline response element (TRE), and forebrain, neuronal-specific, targeting was driven by crossing the responder lines to a CaMKII-tTA driver line (Mayford et al. 1996). Given that expressor transgenic lines were driven via the CaMKII promoter, we were able to achieve selective loss and gain of miR-132 andploying a combination of miR-132/-212 conditional knockout goal was to provide an intersectional validation of the miR-132 and miR-212 targeted genes. We predicted that mRNA targets of each of these miRNAs would be upregulated in the hippocampi of cKO animals and downregulated in animals overexpressing their respective miRNA (Lanford et al. 2010; Yang and Qu 2013; Oulas et al. 2015). Further, if one assumes that the two miRNAs do not exhibit functional redundancy, one would predict that a se upregulated genes in the miR-132/-212 knockout should be downregulated in the miR-132 and another set would be downregulated in the miR-212 transgenic mouse lines. Thus, by inversely correlating the hippocampal transcriptomes, a narrower pool of putative targets emerge for each miRNA (Fig. 3A).

The CaMKII-tTA::miR-132 animals exhibit an approximate fivefold increase in miR-132 over endogenous levels in the hippocampus (Hansen et al. 2010, 2013), and the CaMKII-tTA::miR-212 animals exhibit an approximate twofold increase in miR-212 over endogenous levels in the hippocampus (Fig. 4B). As an initial screen for a behavioral effect of the transgene, we employed the novel object recognition test outlined above. Interestingly, CaMKII-tTA::miR212 exhibited a significant deficit in recognition memory, compared to control littermates without the CaMKII-tTA driver (Fig. 4C), thus indicating that, as with miR-132, miR-212 can also affect cognitive capacity.

To profile gene expression via RNA-seq, we isolated RNA from the hippocampi of CaMKII-Cre::miR-132/212 $2^{\mathrm{f} / \mathrm{f}}$, CaMKII-tTA::miR-132, and CaMKII-tTA::miR-212 animals, as well as their respective nontransgenic controls. Control mice were transgenic for the driver (i.e., CaMKII-Cre or CaMKII-tTA), but lacked the responder transgene target. All three mouse lines showed marked changes in mRNA expression (Supplemental Table 1). The CaMKIICre::miR-132/-212 $2^{\mathrm{f} / \mathrm{f}}$ hippocampal transcriptome had 1138 significantly upregulated transcripts, while 886 were significantly downregulated. Transgenic overexpression of miR-132 yielded 1266 upregulated and 928 downregulated genes within the hippocampus, whereas overexpression of miR-212 only resulted in 78 unregulated and 58 downregulated genes. Of those transcripts that were 
A

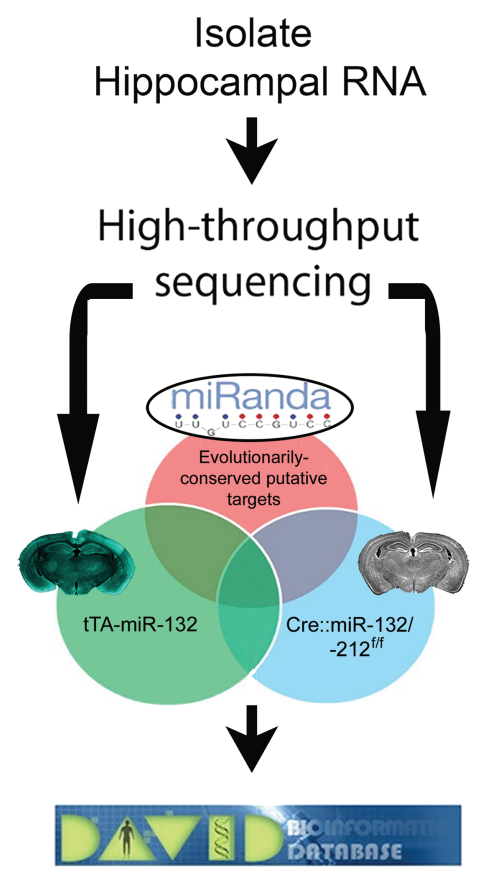

B
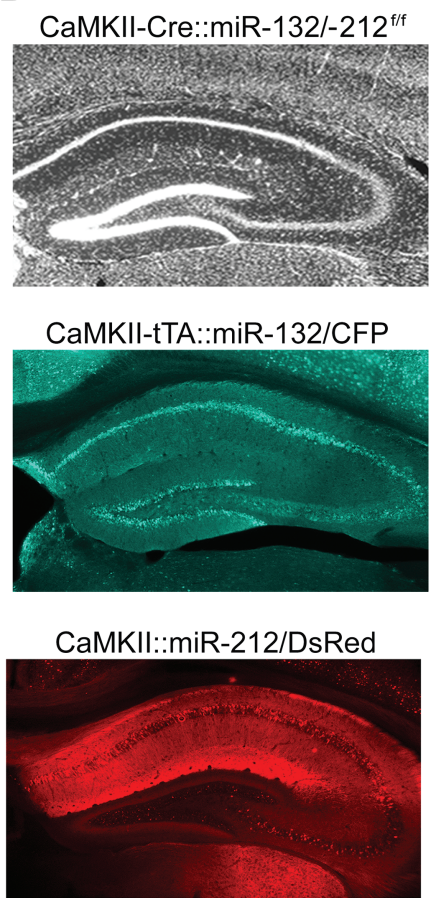

Figure 3. High-throughput sequencing of the hippocampal transcriptome in tTA::miR-132, tTA::miR-212, and CaMKII-Cre::miR-132/-212 $2^{\mathrm{f} / \mathrm{f}}$ animals. (A) Hippocampal mRNAs were sequenced from tTA::miR-132, tTA::miR-212, and CaMKII-Cre::miR-132/-212 $2^{\mathrm{f} / \mathrm{f}}$ animals using the Illumina approach, followed by functional gene ontology analysis on the intersection of direction-specific gene alterations to determine the molecular effects of altered miR-132 and miR-212. Of note, for the sake of clarity, the schematic omits the intersection analysis for the tTA::miR-212 mouse line. (B) Representative hippocampal images from the three noted mouse lines. Hoechst labeling was used to delineate the hippocampal sublayers of the CaMKII-Cre::miR-132/-212 $2^{\mathrm{f} / \mathrm{f}}$ line. The miR-132 and miR-212 transgenic lines express cyan fluorescent protein (CFP) or RsRED, respectively, from bidirectional TRE transgenic promoter constructs (refer to the Methods section for a description of the transgenes).

upregulated in the cKO animals, 96 and 4 were also downregulated in the tTA::miR-132 and tTA::miR-212 lines, respectively.

To begin to identify mRNA targets that may mediate the learning and memory phenotypes associated with miR-132/-212, we performed ontological analysis of those mRNAs that were altered in our transgenic lines. With regard to miR-132, we found an enrichment of genes related to neurogenesis and proliferation, as well as those involved in the regulation of morphological projection (Fig. 5A; Supplemental Table 2A). mRNAs that were dysregulated in the miR-212 transgenic animals were also associated with neuronal projection, in addition to the regulation of synaptic transmission and transcriptional regulation (Fig. 5B; Supplemental Table 2B). To further narrow the pool of predicted miRNA targets and to differentiate direct targets from those mRNAs that may be dysregulated as downstream effects of this regulation, we included an intersection of our data with informatically predicted, and evolutionarily conserved miR-132 and miR-212 targets with good mirSVR scores (Betel et al. 2008; Szeto et al. 2014). Next, we compared those transcripts that were significantly upregulated in the cKO animals with those downregulated in each tTA transgenic line. Together, these intersections yielded 18 mRNAs that fit the qualifications
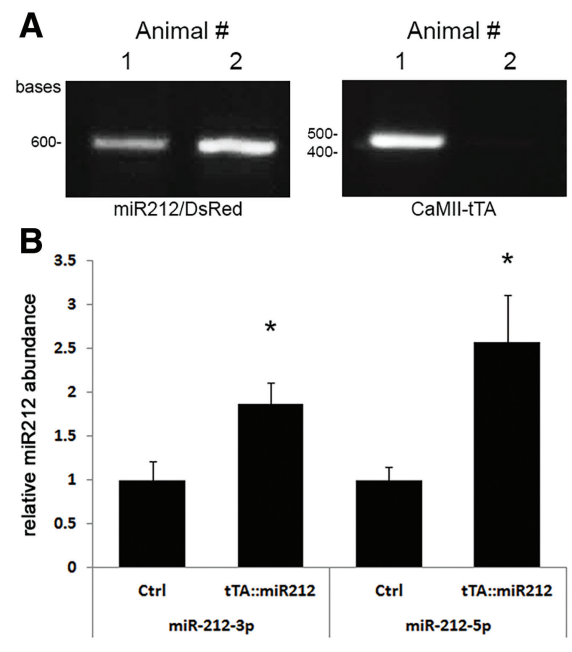

C

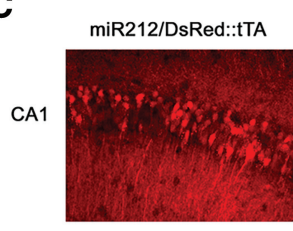

CA3

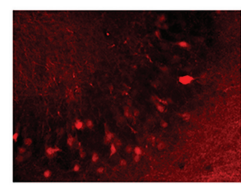

GCL

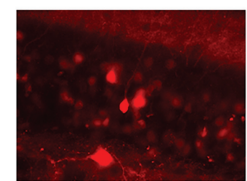

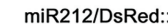
no driver
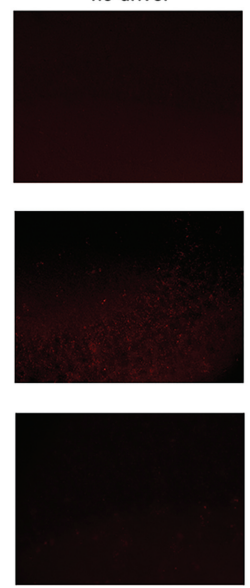

D

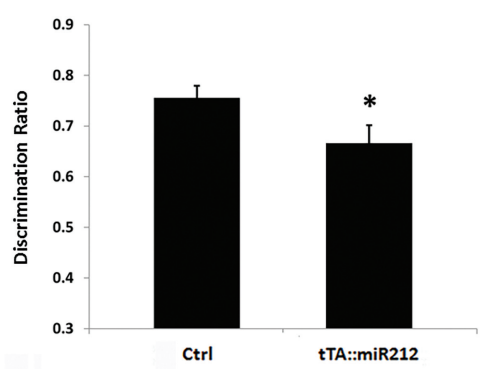

Figure 4. miR-212/dsRED transgene expression. $(A)$ Polymerase chain reaction (PCR)-based genotyping results for miR-212 and tTA. PCRs were run in a $1 \%$ agarose gel and visualized using ethidium bromide. Animal 1 represents an animal transgenically expressing miR-212 under the control of the CamKII-tTA driver, whereas Animal 2 has the miR-212 transgene, but lacks the driver and thus does not express the miR-212 transgene. (B) qPCR was performed to profile levels of miR-212 within the hippocampus; both the miR-212 sense strand (miR-212-3p) and anti-sense strand (miR-212-5p) were profiled. Mature miR-212 levels are shown as mean \pm SEM, compared with nontransgenic controls (Ctrl: $n=4$ animals per condition). Data were normalized to the control conditions which were set to a value of 1 . (C) Coronal brains sections show fluorescence from the dsRED transgene marker within the CA1, CA3, and granule cell layer $(G C L)$ of the hippocampus. $(D)$ The novel object recognition task revealed an impaired recognition memory phenotype in tTA::miR-212 animals. Discrimination ratio $=$ (exploration time with novel object)/(total exploration time). Data are presented as mean \pm SEM, $n=6 /$ group, $(*) P<0.05$, Student's $t$-test. 
A

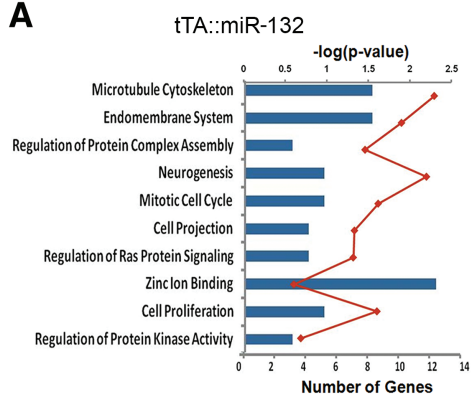

C

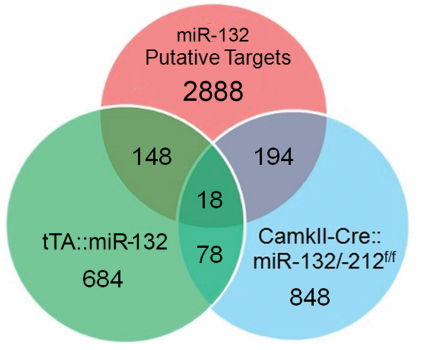

B

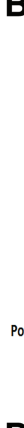

D

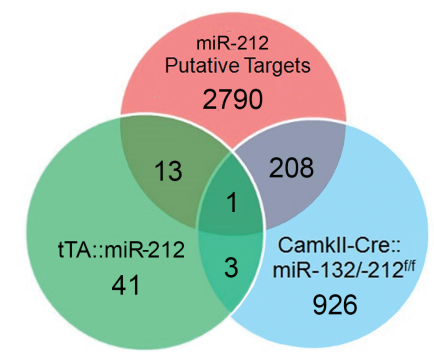

Figure 5. Enriched ontological clusters of altered mRNA in miR-132 and miR-212 transgenic mice. $(A, B)$ Using a ranked list of genes downregulated following miRNA overexpression, the top 10 clusters of DAVID categories were sorted by enrichment score and presented for each of the transgenic animal lines (tTA::miR-132 and tTA::miR-212). The number of genes within each cluster is reported as a bar corresponding to the lower axis. In addition, EASE scores (DAVID's modified Fischer exact $P$-value) for each cluster are depicted as a measure of the association strength of genes within each cluster with a line graph corresponding to the upper axis. $(C, D)$ Upregulated genes from CaMKII-Cre::miR$132 /-212^{\mathrm{f} / \mathrm{f}}$ animals were compared with genes downregulated in tTA::miR-132 and tTA::miR-212 animals, respectively, as well as with algorithmic target predictions from microRNA.org. This intersection yielded a limited pool of potential targets for each miRNA.

for all three miR-132 datasets (Table 1; Fig. 5C), and only one mRNA that overlapped with the miR-212 datasets (Fig. 5D).

\section{Altered STXIA and MASHI expression in CaMKII-Cre::miR-132/-212 $2^{\mathrm{f} / \mathrm{f}}$ animals}

The intersected miR-132 datasets yielded a number of mRNAs of potential neurophysiological importance. Among these, the basic helix-loop-helix (bHLH) transcription factor Mash1 was of particular interest because of its role in progenitor cell development and cell fate determination within the subgranular zone (SGZ) of the adult dentate gyrus (Kim et al. 2007, 2011). We examined levels of MASH1 expression within the SGZ in cKO animals via immunohistochemical labeling. This analysis revealed a significant increase in MASH1-positive cells within the SGZ relative to controls (Fig. 6A,B), paralleling our RNA-seq data indicating increases in Mash1 mRNA following miR-132/-212 deletion.

In contrast to miR-132, the miR-212 intersection yielded only one mRNA common to all three datasets: Stx1a. Nevertheless, as a critical protein involved in the docking of synaptic vesicles and the regulation of $\mathrm{Ca}^{2+}$-dependent neurotransmitter release (Söllner et al. 1993a,b), Stx1a has potential as a mediator of miR-132/-212's effects on cognition. Indeed, Stx $1 a$ is strongly implicated in the autism spectrum disorders (ASDs) and other cognitive disorders (Gao et al. 2010b; Durdiaková et al. 2014). An immunohistochemical analysis of STX1A expression within stratum oriens and stratum radiatum (two regions that exhibit robust levels of STX1A; Ruiz-Montasell et al. 1996) revealed a marked increase in STX1A in cKO mice relative to control animals (Fig. $6 \mathrm{~B}, \mathrm{D})$. Together, these data strongly support the idea that endogenous miR-212 targets STX1A in the hippocampus.

\section{Discussion}

Here, we employed a conditional knock out approach to delete the miR-132/212 gene cluster from excitatory forebrain neurons. We observed behavioral impairment in spatial and recognition memory in these animals, as demonstrated by novel object recognition, contextual fear conditioning, and Barnes maze paradigms. miR-132 and miR-212 are known to target a range of neuronal mRNAs that may contribute to these effects, including MeCP2, p250GAP, AChE, and $\mathrm{K}_{\mathrm{ir}} 2.1$ (Klein et al. 2007; Wayman et al. 2008; Goldoni et al. 2012; Shaltiel et al. 2013). The cognitive defects presented here are also in line with the altered expression of miR-132/-212 observed in a variety of neurocognitive disorders (Lukiw 2007; Johnson et al. 2008; Miller et al. 2012). Further, consistent with the work reported here, a recent paper by HernandezRapp et al. (2015) reported that germline miR132 KO mice exhibit novel object recognition and spatial memory deficits. Collectively, these data position miR$212 / 132$ among a number of other CREB-regulated genes that are required for learning and memory formation (Hall et al. 2001; Colombo et al. 2003). Indeed, CREB-dependent transcription is induced following an array of learning paradigms and is required for normal cognitive function (Impey et al. 1998; Mizuno et al. 2002; Porte et al. 2008). Nevertheless, while moderate increases in CREB activity facilitate learning, chronic enhancement of CREB-dependent transcription impairs cognitive capacity, paralleling the learning phenotypes observed in tTA::miR-132 animals (Viosca et al. 2009; Hansen et al. 2013).

Table 1. Genes appearing in all three datasets for predicting miR-132 targets

\begin{tabular}{lcl}
\hline Genes & cKO FC & tTA::miR-132 FC \\
\hline Pbx4 & 18.94 & -3.86 \\
Mash1 & 11.37 & -2.99 \\
Cldn1 & 3.65 & -4.32 \\
Rps6kc1 & 3.65 & -1.72 \\
2310022A10Rik & 3.06 & -1.22 \\
Rb1 & 2.55 & -1.45 \\
Mapkapk5 & 2.23 & -1.78 \\
Enpp2 & 1.91 & -1.52 \\
Eprs & 1.76 & -1.51 \\
Ntrk3 & 1.57 & -1.65 \\
Bnip2 & 1.55 & -1.58 \\
Fam3c & 1.52 & -1.89 \\
Et14 & 1.40 & -1.44 \\
Gdap1 & 1.35 & -1.59 \\
Tusc3 & 1.26 & -1.20 \\
Pnma2 & 1.22 & -1.38 \\
Rbm18 & 1.18 & -1.87 \\
Atp2b1 & 1.10 & -1.26
\end{tabular}

Here, we present the 18 genes that are significantly increased in CaMKII-Cre::miR-132/-212/f animals, decreased in tTA::miR-132 animals, and that appear as informatically predicted targets of miR-132. Fold changes in expression for each animal line is also included. ( $F C=$ fold change). 

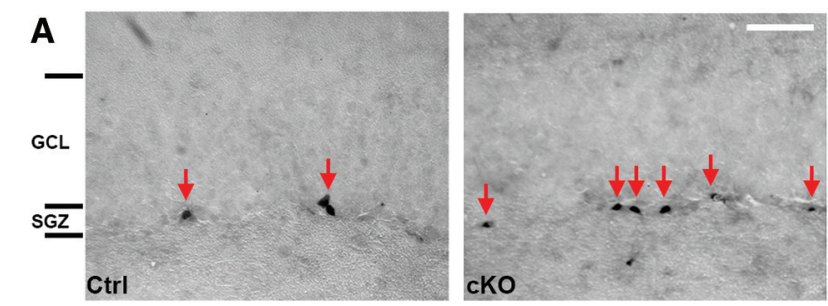

B

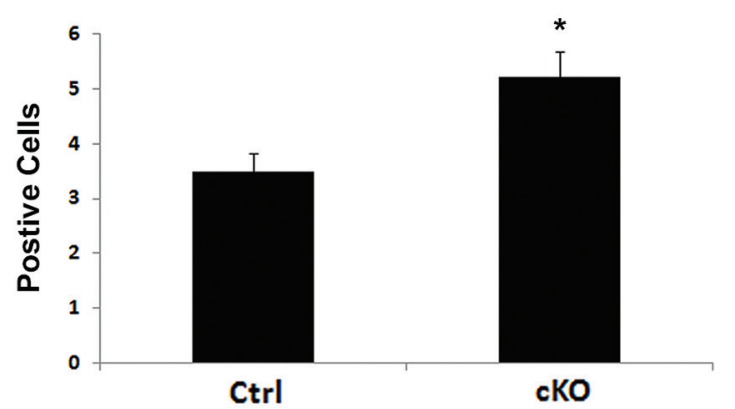

C
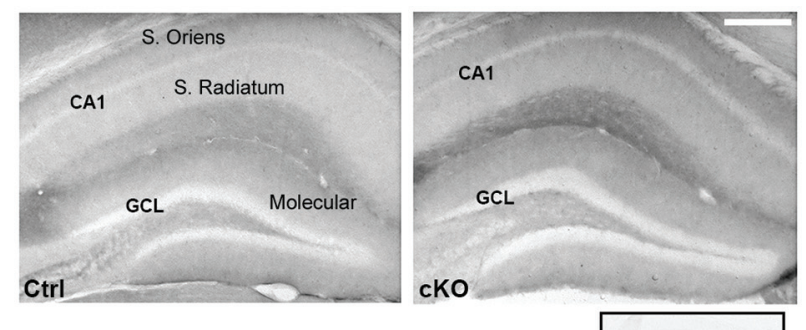

D

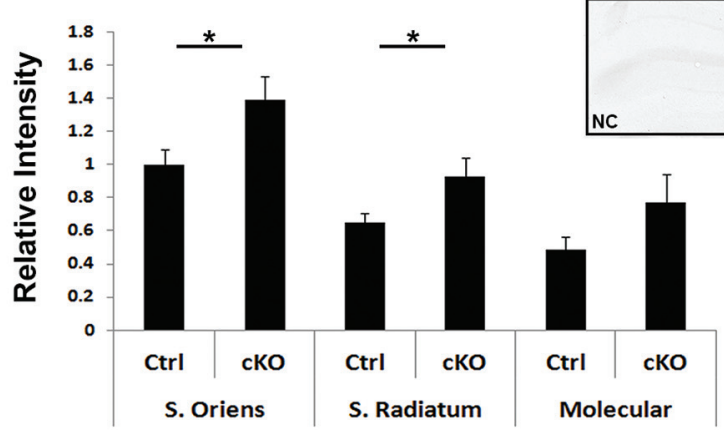

Figure 6. Increased MASH1 and STX1A expression following deletion of miR-132/-212. (A) CaMKII-Cre::miR-132/-212 ${ }^{\mathrm{f} / \mathrm{f}}$ (cKO) animals exhibit an increase in MASH1-positive cells within the subgranular zone of the hippocampus, as demonstrated by DAB-based immunolabeling. Arrows indicate MASH1-positive cells, scale bar $=25 \mu \mathrm{m} ; \mathrm{GCL}=$ granule cell layer, $\mathrm{SGZ}=$ subgranular zone. (B) Quantification of MASH1-positive cells in cKO tissue relative to control animals with intact miR-132/-212 ((*) $P<0.05) ; n=6$ animals per group. (C) CKO animals also showed an increase in STX1A expression in the stratum oriens (S. Oriens), and then stratum radiatum (S. Radiatum) relative to control animals. Tissue that was processed without the addition of primary antibody is provided as a negative control (NC) in the inset. Scale bar $=150 \mu \mathrm{m}$. (D) Quantification of STX1A staining intensity within the S. Radiatum, S. Oriens, and molecular layers in CKO animals relative to controls $\left(\left(^{*}\right) P<0.05\right)$, Student's $t$-test; $n=7$ animals per group. Values were normalized to labeling in the control $S$. Oriens, which was set equal to a value of 1 .

To identify potentially new mechanisms of miR-132/-212 regulation with regard to learning and memory, we sequenced the transcriptomes of the hippocampi of CaMKII-Cre::miR$132 /-212^{\mathrm{f} / \mathrm{f}}$ animals, as well as those of the CaMKII-tTA::miR132 and CaMKII-tTA::miR-212 animals. As a result, we were able to identify a pool of mRNA transcripts with altered expression following conditional deletion and/or transgenic increases in miR-132 and miR-212 expression. Among these, the transcript encoding the bHLH transcription factor MASH1 was identified as a hippocampal mRNA that showed increased expression in cKO animals and decreased expression in the tTA::miR-132 line. Consistent with our RNA-seq data, we also observed increases in MASH1 protein expression by immunolabeling within the SGZ of cKO animals. Within the adult hippocampus, MASH1-positive cells have the potential to develop into either oligodendrocytes or neurons, with higher levels of MASH1 indicating a neuronal fate (Aguirre et al. 2004; Parras et al. 2004; Kim et al. 2011). MASH1 primarily defines type-2a progenitor cells and some late stage type-1 stem cells that eventually mature into granule neurons, though some MASH1-positive cells remain as progenitors within the SGZ for extended periods of time, up to 6 mo (Kim et al. 2007; Vasconcelos and Castro 2014).

Here, it is important to note that CaMKII-driven transgene expression occurs in developing doublecortin-positive neurons of the SGZ (Chan et al. 2008; Choi et al. 2009; our unpublished observations). This parallels the time course of expression of WT miR-132, which increases in expression within doublecortinand NeuN-positive cells, but is absent in nestin-positive precursors (Luikart et al. 2011). Collectively, these observations suggest that the miR-132/-212 locus is excised by the Cre driver in maturing granule cells in our cKO animals. Hence, at this point it is not clear whether the effects of miR-132 on MASH1 expression are cell autonomous or are the result of the indirect action of miR-132 functioning in post-mitotic adult neurons. However, it is apparent that the upregulation of miR-132 in developing SGZ-derived neu- rons occurs during or after MASH1 has been downregulated (Kim et al. 2011). Within the context of a cell autonomous model, there may be several possible mechanisms to explain the temporal discord between the expression of miR-132 and its putative target, MASH1. While a combination of transcriptional mechanisms are likely used to repress MASH1, the rapid upregulation of miR-132 that coincides with neurogenesis may function as a critical downregulation mechanism for MASH1 translation in the SGZ. As a result of this, the increased number of MASH1positive cells in the $\mathrm{CKO}$ animals may have resulted in an accumulation of late stage progenitor cells that have yet to transition into an immature neuronal phenotype. Thus, in this model, ectopic MASH1 expression may inhibit the proper exiting of progenitors from the SGZ and delay development into mature neurons. Clearly, the increased expression of MASH1 observed in cKO animals has the potential to yield a range of deficits within the SGZ and therefore affect neuronal development, integration, and hippocampal function. Additional experiments will be necessary to determine the precise mechanism of miR-132 action on MASH1 and how this interaction may imediate any subsequent cognitive impairment.

Of those mRNA that were downregulated in animals overexpressing miR-212, only one, Stx $1 a$, showed a significant increase in expression following miR-132/-212 conditional deletion. Using immunohistochemical labeling, we also showed a concordant increase in STX1A protein expression within the hippocampus of cKO animals. STX1A plays a central role in the docking of presynaptic vesicles via the formation of the SNARE complex and is required for normal hippocampal LTP (Bennett et al. 1992; Mishima et al. 2012). While STX1A is essential for voltagedependent calcium and potassium signaling (and thus for synaptic transmission), its overexpression inhibits exocytosis and blocking STX1A enhances $\mathrm{Ca}^{2+}$ influx into cells via N-type calcium channels (Mitchell and Ryan 2005; Swayne et al. 2005). Given that both deletion and overexpression of miR-132 lead 
to cognitive defect (Hansen et al. 2013), it would not be surprising if miR-212 functioned in a similar manner, requiring a tightly regulated, narrow range of expression to properly regulate its mRNA targets in facilitating normal learning and memory formation. Of note, while miR-212 is increased following seizure activity, STX1A is decreased after kainic acid administration along a similar time course as miR-212 expression, further strengthening the evidence for inhibitory regulation of Stx $1 a$ by miR-212 (Fujino et al. 1997; Nudelman et al. 2010). Taken together, these data raise the prospect that aberrant miR-212 expression could contribute to several neuronal disorders associated with STX1A and cognitive impairment (Nakamura et al. 2008; Sánchez-Mora et al. 2013).

While there are some prominent mRNAs that are targeted by both miR-132 and miR-212 (e.g., MeCP2; Klein et al. 2007; Im et al. 2010; Wada et al. 2010), these miRNAs have also been shown to target distinct populations of mRNAs as well (Kumarswamy et al. 2014). Though miR-132 and miR-212 share the same seed sequence, the rest of their nucleotide sequences differ from one another. These non-seed regions play an important role in directing mRNA targeting, and therefore potentially have a dramatic effect on the regulatory capacity of each miRNA (Breving and Esquela-Kerscher 2010; Sun et al. 2010). Furthermore, while their transcriptional expression may be quite similar, miR-132 and miR-212 may undergo substantially different posttranscriptional regulation. Indeed, differences in expression or degradation with regard to time of day, brain region, and cell type may further differentiate the regulatory functions of these miRNAs. In addition, other factors such as miRNA subcellular localization, turnover rates, and mRNA 3' UTR binding site abundance may also result in divergent functions for these miRNA (Kumarswamy et al. 2014).

Here, our RNA-seq data suggest somewhat distinct roles for miR-132 and miR-212. While there is known overlap in some of their targets and functions, in our hands few of the mRNA alterations in their respective overexpression transcriptomes coincided. In addition, our results revealed substantially more downregulated mRNA transcripts in tTA::miR-132 animals than in tTA::miR-212 animals. While this may be a function of the higher transgenic expression of miR-132 than miR-212 in the respective animal models employed here, there is evidence to suggest that miR-132 is the predominant miRNA of the miR-132/-212 locus expressed in the WT hippocampus (Magill et al. 2010). In demonstrating their relative expression, Magill et al. used ratiometric sensors that incorporated complementary miRNA recognition elements (MREs) into the 3' UTR of a GRP reporter, which was transcribed using a bidirectional promotor to additionally express a stable DsRED reporter lacking any MREs. Thus, by transfecting cultured hippocampal neurons with these sensors and measuring relative florescence by flow cytometry, they were able to assess the comparative abundance of each miRNA in the miR-132/-212 cluster, revealing the predominance of miR-132 expression within the hippocampus. Nevertheless, the relative expression of the miR-132/-212 miRNAs may vary significantly depending on the brain region or cell type that is profiled. Indeed, within the context of striatum-dependent regulation of addiction, miR-212 may be the more dominant miRNA (Hollander et al. 2010; Im et al. 2010). Hence, while these miRNA may have emerged out of an evolutionary duplication early in the vertebrate lineage, they have since diverged into two functionally distinct miRNAs.

Thus, miR-132 and miR-212 may have both distinct as well as overlapping roles within the CNS. The means of precise coordination between these miRNAs in the regulation of hippocampaldependent learning merits additional study. Indeed, given their dysregulation within several neurocognitive disorders, miR-
132/-212 may eventually serve as reliable biomarkers for cognitive dysfunction, or ultimately even as potential therapeutic targets for such disorders (Klein et al. 2007; Cogswell et al. 2008; Kim et al. 2010; Wang et al. 2011; Sheinerman et al. 2013; Burgos et al. 2014).

\section{Materials and Methods}

\section{Conditional deletion and transgenic expression of miR-132 and miR-212}

We employed a Cre-lox system to selectively excise the miR-132/-212 locus from excitatory forebrain neurons (animals are denoted: CamKII-Cre::miR-132 $\left.{ }^{\mathrm{f} / \mathrm{f}}\right)$. miR-132/-212 $2^{\mathrm{f} / \mathrm{f}}$ animals were provided by Dr. Simon Arthur at the University of Dundee, Dundee, United Kingdom, and have been described previously (Remenyi et al. 2013). These animals, which were generated in ES cells derived from $\mathrm{C} 57 \mathrm{Bl} / 6 \mathrm{~N}$ mice, were crossed to a CaMKII-driven Cre recombinase line (Tsien et al. 1996; acquired from Jackson Labs; stock \#: 005359) to target deletion of the miR-132/-212 locus. Animals without the CaMKII-Cre driver served as controls. The efficacy of the CaMKII-Cre deletor line was validated by crossing it to the ROSA $26 \beta$-galactosidase CRE reporter line (Soriano 1999; acquired from Jackson labs; stock \#: 003474). In addition, we used a CaMKII Tet-off (tTA) mouse line (Mayford et al. 1996; acquired from Jackson Labs; stock \#:003010) to overexpress miR-212 (denoted as the tTA::miR-212 animal line) in excitatory forebrain neurons in conjunction with a dsRED biomarker. To generate this miR-212 transgenic line, $199 \mathrm{bp}$ of mouse genomic DNA flanking pre miR-212 was PCR-amplified from a C57/Bl6 mouse tail DNA (Primer F: GAGGCGCTTGCACTGCATCAGCACCG; Primer R: AACTGCGG GCGACGGGATATCCCCG). The fragment was cloned into the pTRE-Tight-BI-DsRed-Express Vector and the mature miR-212-3p and miR-212-5p expression was confirmed by co-transfection with tTA expression vector in HEK 293 cells followed by RTPCR. The production of the transgenic mice was conducted by pronuclear injection of $\sim 1.1 \mathrm{~kb}$ long XbaI-HinIII-digested DsRed-biTRE-miR-212 DNA into fertilized mouse eggs (FVB strain). Two founder lines were crossed with CamKII driven-TTA expressing mice (C57/Bl6 strain), and the bi-transgenic line was bread into the C57/B16 background strain at least five additional generations. Transgenic miR-212 expression was profiled using the NCode VILOmiRNA cDNA Synthesis Kit (Invitrogen), SYBR green reporter-based qPCR (Applied Biosystems) and miScript Primers (Qiagen), following manufacturer guidelines. We also employed the CamKII tTA::miR-132 transgenic animal line, which was developed as previously described (Hansen et al. 2010). Of note, the miR-132 transgenic mouse line was generated in an FVB background and crossed into a C $57 \mathrm{Bl} / 6 \mathrm{~J}$ background 5 times. All animal breeding and experimental procedures were approved by the Ohio State University Animal Care and Use Committee (protocol number: 2008A0227).

\section{Behavioral analysis}

Mature (6-8 wk), sex-matched mice with the noted transgenes were used. Control mice were transgenic for the driver (i.e., CaMKII-Cre or CaMKII-tTA), but lacked the responder transgene target. All of these transgenes were maintained in C57/B16 line. All animals were screened for vision by suspending the animal by the tail and slowly lowering it toward a sold dark surface (a table) for three successive trials. Visual acuity was considered intact if animals reached for the surface before vibrissae made physical contact with it. Auditory acuity was established by freezing behavior in response to three successive, loud claps emitted out of visible range of the animal. Hearing capacity was indicated by a positive freeze response from each animal. All mice demonstrated full visual and auditory capability by these criteria.

The novel object recognition assay was adapted from procedures described by Bevins and Besheer (2006). In brief, animals were allowed to explore an arena containing two identical objects 
for $10 \mathrm{~min}$, followed by a 30-min retention interval once returned to their home cage. Animals were then returned to the exploration arena in which one object was replaced with a novel, unexplored object. Animals were allowed $5 \mathrm{~min}$ to explore, during which the time spent exploring each object was recorded. Exploration of an object was defined as the animal's nose being within $2 \mathrm{~cm}$ of, and pointed toward, the object. Results were reported as a discrimination ration, which was calculated as [exploration time with the novel object]/[total exploration time]. Objects and exploration areas were cleaned with $70 \%$ ethanol between each trial.

The Barnes maze assay was adapted from Sunyer et al. (2007). Animals were placed at the center of an elevated circular elevated maze with 20 equally spaced holes around the perimeter. An escape box was provided under one of these holes and animals were given $5 \mathrm{~d}$ (three trails per day) to learn to escape to this target. Each trial consisted of 5-min of free exploration followed by a 10-min inter-trial interval. Bright light (580 lux) and an electronic metronome (Boss DB-66, $74 \mathrm{~dB}, 120$ beats per minute [bpm]) were used as mildly aversive stimuli to motivate escape to the target hole. Visual cues were placed on the walls surrounding the Barnes maze platform. All surfaces were cleaned with 70\% ethanol following each trial.

Contextual and tone fear conditioning were performed according to procedures described by Wehner and Radcliffe (2004). Animals were allowed to explore a novel arena for 3 min, followed by a tone $(85 \mathrm{~dB}, 2400 \mathrm{~Hz})$ emitted for $30 \mathrm{sec}$. Following a 28-sec delay, animals received a mild $(0.6 \mathrm{~mA})$ shock stimulus for $2 \mathrm{sec}$. Animals underwent two subsequent shock and delay periods before being returned to their home cage. The following day, animals were returned to the shock context, but no shock was administered. Animals were given $4 \mathrm{~min}$ to explore the context while being observed over 8-sec intervals for freezing behavior. Subsequently, animals were also placed in a novel context. After 2 min of exploration time, animals were presented with the tone stimulus for $3 \mathrm{~min}$ while being observed for freezing behavior over 8-sec intervals.

\section{Behavioral statistics}

Unless otherwise noted, values are presented as means \pm SEM and were performed by SPSS 19.0. Comparisons between two groups were made by Student's $t$-test, whereas a repeated-measures mixed model ANOVA was used for multiday Barnes maze training comparison. $N$ values are provided in the figure legends.

\section{Fluorescent in situ hybridization}

All tissue isolation and preparation was carried out under RNase-free conditions, using of DEPC-treated solutions. Animals were sacrificed by cervical dislocation. Brain tissue was removed, fixed in $4 \%$ paraformaldehyde for $6 \mathrm{~h}$ at $4^{\circ} \mathrm{C}$, and cryoprotected with $30 \%$ sucrose in phosphate-buffered saline. Sections were then thin cut to $40 \mu \mathrm{m}$ on a freezing microtome. Fluorescent in situ hybridization (FISH) against miR-132 was performed following the guidelines of Nuovo (2010). Mounted tissue was treated with a brief (20 min) pepsin digestion, and hybridized with a fluorescein-conjugated locked nucleic acid (LNA) probe against miR-132 (Aquired from Exiqon Inc.; Obernosterer et al. 2007) overnight. The signal was amplified using an anti-fluorescein Alexa 488 signal detection kit (Invitrogen). Images were acquired using Zeiss 510 confocal microscope and LSM Software, Zen.

\section{DAB immunolabeling}

Brain tissue was fixed by transcardial perfusion with $4 \%$ paraformaldehyde, under ketamine/xylazine anesthesia. Brains were then isolated and post-fixed with $4 \%$ paraformaldehyde for $6 \mathrm{~h}$ at $4^{\circ} \mathrm{C}$. Tissue was then cryoprotected and sliced as described above. Thin sections were subsequently washed and permeabilized in 1\% Triton X-100 in PBST (3x, 10 min each). Sections incubated in $0.3 \%$ hydrogen peroxide/PBS for $20 \mathrm{~min}$ to eliminate endogenous peroxidase activity and subsequently blocked in
$10 \%$ normal goat serum or normal horse serum in PBS for 1 $\mathrm{h}$. Sections were then incubated with primary antibody overnight at $4^{\circ} \mathrm{C}$ using mouse polyclonal anti-MASH1 (1:50 dilution; cata$\log 556604$; BD Pharmingen) or rabbit polyclonal anti-Syntaxin 1a (1:500; dilution; catalog 41753; Abcam). The following day, sections were washed and incubated with biotin-conjugated horse anti-mouse IgG or goat anti-rabbit IgG secondary antibody (1:500 dilutions; Vector Laboratories) for $2 \mathrm{~h}$. The ABC labeling (Vector Labs) followed by DAB development (Vector Labs) was used to visualize the signal. Sections were mounted on gelatin-coated slides with Permount Mounting Medium (Fisher Chemical). Images were captured using a 16 bit digital camera (Micromax YHS 1300; Princeton Instruments) mounted on an inverted Leica microscope (DM IRB). Single cell counting at $20 \times$ magnification was used to quantify MASH1-positive cells. Initially, the SGZ zone was defined as a $30 \mu \mathrm{m}$-thick wide dorso-ventral region between the hilus and granule cell layers. Immunopositive cells were then counted bilaterally in four coronal sections starting at Bregma $-1.70 \mathrm{~mm}$. Data were then averaged and presented as the average cells per hemisphere. For Syntaxin 1A labeling, densitometric analysis of the stratum oriens, stratum radiatum, and upper molecular layer of the dentate gyrus was performed in four coronal sections per animal starting at Bregma $-1.70 \mathrm{~mm}$. For this analysis, Metamorph software (Universal Imaging, West Chester, PA) was used to place digital rectangles $(40 \mu \mathrm{m}$ dorso/ ventral $\times 80 \mu \mathrm{m}$ medio/lateral) over the three noted regions $(10 \times$ magnification) and the average intensity values (4096 scale) were captured and background subtracted using nonlabeled images of the lateral ventricles. Data were captured by centering the rectangles on the dorsal apex of each region. The corrected values were averaged for each animal and data were presented as the mean \pm the SEM for each region and significant differences were assessed via the Student's $t$-test. All data collection and analysis were performed by an individual "blinded" to experimental groups.

\section{Immunofluorescent staining}

Tissue was isolated, fixed, sectioned, and permeabilized as described above. Tissue was blocked in $10 \%$ normal goat serum in PBS for $1 \mathrm{~h}$, followed by an overnight incubation at $4^{\circ} \mathrm{C}$ with chicken polyclonal anti-GFP (1:2500 dilution; catalog 13970; Abcam). Following washes, sections were incubated with Alexa Fluor-488-conjugated goat anti-chicken IgG antibody (1:2000 dilution; Invitrogen) for $2 \mathrm{~h}$. No antibody amplification was necessary for the tTA::miR-212 dsRED signal. Sections were also incubated for $10 \mathrm{~min}$ with the nuclear stain DRAQ5 (1:10,000 dilution; BioStatus Limited, UK and Hoechst 33258 (1:1000 dilution: Sigma), followed by an additional three 10-min washes. Sections were mounted on slides with Fluoromount-G (SouthernBiotech) and images captured using a 16-bit digital camera (Micromax YHS 1300; Princeton Instruments) mounted on an inverted Leica microscope (DM IRB).

\section{Illumina sequencing and analysis}

For a detailed outline of the RNA isolation, library preparation and sequencing please refer to our recent paper (Hansen et al. 2014). Briefly, hippocampal mRNA was isolated from CaMKIICre::miR-132/-212 $2^{\text {/f }}$, tTA::miR-132, and tTA::miR-212 animals, as well as their respective nontransgenic controls. Next, polyadenylated RNA was purified from $1 \mu \mathrm{g}$ of total RNA per animal via the Dynabeads mRNA purification kit (Life Technologies \#61006). cDNA from six animals was pooled into two or three independent biological replicates for each condition. Libraries were prepared using the Illumina TruSeq RNA Library Preparation Kit v2 per the manufacturer's instructions and sequenced using an Illumina Genome Analyzer IIx; Samples were sequenced at a concentration of $10 \mathrm{pM}$ per condition. Of note, library preparation, and the RNA sequencing for each of the three mouse lines (and their nontransgenic controls) were performed on separate occasions over a 6 mo period. Base-calling was conducted with the standard Illumina Analysis Pipeline 1.0 (Firescrest-Bustard) and 
sequences were aligned to the UCSC $\mathrm{mm} 9$ reference genome using Bowtie v0.12.7. Custom $\mathrm{R}$ scripts were used to quantify the number of uniquely mapped reads within exons of UCSC $\mathrm{mm} 9$ Ref-Seq genes; Sequence data have been submitted to the NCBI Short Read Archive with accession number GSE73413.

The Bioconductor DESeq2 package (v1.4.0, http://www .bioconductor.org/packages/devel/bioc/html/DESeq2.html: Anders and Huber, 2010) was applied to generate normalized read counts and ratio test for differential expression. The Storey Q-test (Bioconductor qvalue package) was used to correct for multiple comparisons as well as to generate a standard false-discovery rate correction. Relative abundance was measured in fragments per kilobase of exon per million fragments mapped using Cufflinks v1.2. Differentially regulated Ref-Seq genes with a $q<0.05$ and fold change absolute value $>1.2$ were considered significant. The web-based annotation tool DAVID v 6.7 (Database for Annotation, Visualization and Integrated Discovery) was used to cluster differentially expressed genes by their enriched ontologies (Huang et al. 2009).

\section{Acknowledgments}

We thank Ashley Garcia, Diego Alzate Correa, and Heather Dziema for technical support. Funding was provided by the National Institutes of Health (grant numbers: F31-MH096460, NS066345, NS091302, NS045758, MH103361) and the National Science Foundation (grant number: 1354612). The authors have declared that no competing interests exist.

\section{References}

Abdelmohsen K, Hutchison ER, Lee EK, Kuwano Y, Kim MM, Masuda K, Srikantan S, Subaran SS, Marasa BS, Mattson MP, et al. 2010. miR-375 inhibits differentiation of neurites by lowering HuD levels. Mol Cell Biol 30: $4197-4210$.

Aguirre AA, Chittajallu R, Belachew S, Gallo V. 2004. NG2-expressing cells in the subventricular zone are type C-like cells and contribute to interneuron generation in the postnatal hippocampus. J Cell Biol 165: 575-589.

Anders S, Huber W. 2010. Differential expression analysis for sequence count data. Genome Biol 11: R106.

Bennett MK, Calakos N, Scheller RH. 1992. Syntaxin: a synaptic protein implicated in docking of synaptic vesicles at presynaptic active zones. Science 257: 255-259.

Betel D, Wilson M, Gabow A, Marks DS, Sander C. 2008. The microRNA.org resource: targets and expression. Nucleic Acids Res 36: D149-D153.

Bevins RA, Besheer J. 2006. Object recognition in rats and mice: a one-trial non-matching-to-sample learning task to study 'recognition memory'. Nat Protoc 1: 1306-1311.

Breving K, Esquela-Kerscher A. 2010. The complexities of microRNA regulation: mirandering around the rules. Int J Biochem Cell Biol 42: $1316-1329$.

Burgos K, Malenica I, Metpally R, Courtright A, Rakela B, Beach T, Shill H, Adler C, Sabbagh M, Villa S, et al. 2014. Profiles of extracellular miRNA in cerebrospinal fluid and serum from patients with Alzheimer's and Parkinson's diseases correlate with disease status and features of pathology. PLoS One 9: e94839.

Chan JP, Cordeira J, Calderon GA, Iyer LK, Rios M. 2008. Depletion of central BDNF in mice impedes terminal differentiation of new granule neurons in the adult hippocampus. Mol Cell Neurosci 39: 372-383.

Choi SH, Li Y, Parada LF, Sisodia SS. 2009. Regulation of hippocampal progenitor cell survival, proliferation and dendritic development by BDNF. Mol Neurodegener 4: 52 .

Cogswell JP, Ward J, Taylor IA, Waters M, Shi Y, Cannon B, Kelnar K, Kemppainen J, Brown D, Chen C, et al. 2008. Identification of miRNA changes in Alzheimer's disease brain and CSF yields putative biomarkers and insights into disease pathways. J Alzheimers Dis 14: $27-41$.

Cohen JE, Lee PR, Chen S, Li W, Fields RD. 2011. MicroRNA regulation of homeostatic synaptic plasticity. Proc Natl Acad Sci 108: 11650-11655.

Colombo PJ, Brightwell JJ, Countryman RA. 2003. Cognitive strategy-specific increases in phosphorylated cAMP response element-binding protein and c-Fos in the hippocampus and dorsal striatum. I Neurosci 23: 3547-3554.

Cuellar TL, Davis TH, Nelson PT, Loeb GB, Harfe BD, Ullian E, McManus MT. 2008. Dicer loss in striatal neurons produces behavioral and neuroanatomical phenotypes in the absence of neurodegeneration. Proc Natl Acad Sci 105: 5614-5619.

Davis TH, Cuellar TL, Koch SM, Barker AJ, Harfe BD, McManus MT, Ullian EM. 2008. Conditional loss of Dicer disrupts cellular and tissue morphogenesis in the cortex and hippocampus. J Neurosci 28: $4322-4330$.

Dhar M, Zhu M, Impey S, Lambert TJ, Bland T, Karatsoreos IN, Nakazawa T, Appleyard SM, Wayman GA. 2014. Leptin induces hippocampal synaptogenesis via CREB-regulated microRNA-132 suppression of p250GAP. Mol Endocrinol 28: 1073-1087.

Durdiaková J, Warrier V, Banerjee-Basu S, Baron-Cohen S, Chakrabarti B. 2014. STX1A and Asperger syndrome: a replication study. Mol Autism 5: 14 .

Friedman RC, Farh KK, Burge CB, Bartel DP. 2009. Most mammalian mRNAs are conserved targets of microRNAs. Genome Res 19: 92-105.

Fujino I, Fujiwara T, Akagawa K. 1997. Transient decrease of HPC-1/ syntaxin-1A mRNA in the rat hippocampus by kainic acid. Neurosci Res 28: $243-247$.

Gao J, Wang WY, Mao YW, Gräff J, Guan JS, Pan L, Mak G, Kim D, Su SC, Tsai LH. 2010a. A novel pathway regulates memory and plasticity via SIRT1 and miR-134. Nature 466: 1105-1109.

Gao MC, Bellugi U, Dai L, Mills DL, Sobel EM, Lange K, Korenberg JR. $2010 \mathrm{~b}$. Intelligence in Williams Syndrome is related to STX1A, which encodes a component of the presynaptic SNARE complex. PLoS One 5: e10292.

Giraldez AJ, Cinalli RM, Glasner ME, Enright AJ, Thomson JM, Baskerville S, Hammond SM, Bartel DP, Schier AF. 2005. MicroRNAs regulate brain morphogenesis in zebrafish. Science 308: 833-838.

Goldoni D, Yarham JM, McGahon MK, O'Connor A, Guduric-Fuchs J, Edgar K, McDonald DM, Simpson DA, Collins A. 2012. A novel dual-fluorescence strategy for functionally validating microRNA targets in $3^{\prime}$ untranslated regions: regulation of the inward rectifier potassium channel K(ir)2.1 by miR-212. Biochem J 448: 103-113.

Hall J, Thomas KL, Everitt BJ. 2001. Fear memory retrieval induces CREB phosphorylation and Fos expression within the amygdala. Eur $J$ Neurosci 13: 1453-1458.

Hansen KF, Sakamoto K, Wayman GA, Impey S, Obrietan K. 2010. Transgenic miR-132 alters neuronal spine density and impairs novel object recognition memory. PLoS One 5: e15497.

Hansen KF, Karelina K, Sakamoto K, Wayman GA, Impey S, Obrietan K. 2013. miRNA-132: a dynamic regulator of cognitive capacity. Brain Struct Funct 218: 817-831.

Hansen KF, Sakamoto K, Pelz C, Impey S, Obrietan K. 2014. Profiling status epilepticus-induced changes in hippocampal RNA expression using high-throughput RNA sequencing. Sci Rep 4: 6930.

Hernandez-Rapp J, Smith PY, Filali M, Goupil C, Planel E, Magill ST, Goodman RH, Hébert SS. 2015. Memory formation and retention are affected in adult miR-132/212 knockout mice. Behav Brain Res 287: $15-26$.

Hollander JA, Im HI, Amelio AL, Kocerha J, Bali P, Lu Q, Willoughby D, Wahlestedt C, Conkright MD, Kenny PJ. 2010. Striatal microRNA controls cocaine intake through CREB signalling. Nature 466: 197-202.

Huang da W, Sherman BT, Lempicki RA. 2009. Systematic and integrative analysis of large gene lists using DAVID bioinformatics resources. Nat Protoc 4: 44-57.

Im HI, Hollander JA, Bali P, Kenny PJ. 2010. MeCP2 controls BDNF expression and cocaine intake through homeostatic interactions with microRNA-212. Nat Neurosci 13: 1120-1127.

Impey S, Smith DM, Obrietan K, Donahue R, Wade C, Storm DR. 1998. Stimulation of cAMP response element (CRE)-mediated transcription during contextual learning. Nat Neurosci 1: 595-601.

Impey S, Davare M, Lesiak A, Lasiek A, Fortin D, Ando H, Varlamova O, Obrietan K, Soderling TR, Goodman RH, et al. 2010. An activity-induced microRNA controls dendritic spine formation by regulating Rac1-PAK signaling. Mol Cell Neurosci 43: 146-156.

Johnson R, Zuccato C, Belyaev ND, Guest DJ, Cattaneo E, Buckley NJ. 2008. A microRNA-based gene dysregulation pathway in Huntington's disease. Neurobiol Dis 29: 438-445.

Kempf SJ, Casciati A, Buratovic S, Janik D, von Toerne C, Ueffing M, Neff F, Moertl S, Stenerlöw B, Saran A, et al. 2014. The cognitive defects of neonatally irradiated mice are accompanied by changed synaptic plasticity, adult neurogenesis and neuroinflammation. Mol Neurodegener 9: 57.

Kim J, Krichevsky A, Grad Y, Hayes GD, Kosik KS, Church GM, Ruvkun G. 2004. Identification of many microRNAs that copurify with polyribosomes in mammalian neurons. Proc Natl Acad Sci 101: $360-365$

Kim EJ, Leung CT, Reed RR, Johnson JE. 2007. In vivo analysis of Ascl1 defined progenitors reveals distinct developmental dynamics during adult neurogenesis and gliogenesis. J Neurosci 27: 12764-12774. 
Kim AH, Reimers M, Maher B, Williamson V, McMichael O, McClay JL, van den Oord EJ, Riley BP, Kendler KS, Vladimirov VI. 2010. MicroRNA expression profiling in the prefrontal cortex of individuals affected with schizophrenia and bipolar disorders. Schizophr Res 124: 183-191.

Kim EJ, Ables JL, Dickel LK, Eisch AJ, Johnson JE. 2011. Ascl1 (Mash1) defines cells with long-term neurogenic potential in subgranular and subventricular zones in adult mouse brain. PLoS One 6: e18472.

Klein ME, Lioy DT, Ma L, Impey S, Mandel G, Goodman RH. 2007. Homeostatic regulation of MeCP2 expression by a CREB-induced microRNA. Nat Neurosci 10: 1513-1514.

Kumarswamy R, Volkmann I, Beermann J, Napp LC, Jabs O, Bhayadia R, Melk A, Ucar A, Chowdhury K, Lorenzen JM, et al. 2014. Vascular importance of the miR-212/132 cluster. Eur Heart J 35: 3224-3231.

Kye MJ, Neveu P, Lee YS, Zhou M, Steen JA, Sahin M, Kosik KS, Silva AJ. 2011. NMDA mediated contextual conditioning changes miRNA expression. PLoS One 6: e24682.

Lagos-Quintana M, Rauhut R, Yalcin A, Meyer J, Lendeckel W, Tuschl T. 2002. Identification of tissue-specific microRNAs from mouse. Curr Biol 12: $735-739$.

Lambert TJ, Storm DR, Sullivan JM. 2010. MicroRNA132 modulates short-term synaptic plasticity but not basal release probability in hippocampal neurons. PLoS One 5: e15182.

Lanford RE, Hildebrandt-Eriksen ES, Petri A, Persson R, Lindow M, Munk ME, Kauppinen S, Ørum H. 2010. Therapeutic silencing of microRNA-122 in primates with chronic hepatitis $\mathrm{C}$ virus infection. Science 327: 198-201.

Lesiak A, Zhu M, Chen H, Appleyard SM, Impey S, Lein PJ, Wayman GA. 2014. The environmental neurotoxicant PCB 95 promotes synaptogenesis via ryanodine receptor-dependent miR-132 upregulation. J Neurosci 34: 717-725.

Li H, Mao S, Wang H, Zen K, Zhang C, Li L. 2014. MicroRNA-29a modulates axon branching by targeting doublecortin in primary neurons. Protein Cell 5: $160-169$.

Lim LP, Lau NC, Garrett-Engele P, Grimson A, Schelter JM, Castle J, Bartel DP, Linsley PS, Johnson JM. 2005. Microarray analysis shows that some microRNAs downregulate large numbers of target mRNAs. Nature 433: $769-773$.

Lin Q, Wei W, Coelho CM, Li X, Baker-Andresen D, Dudley K, Ratnu VS, Boskovic Z, Kobor MS, Sun YE, et al. 2011. The brain-specific microRNA miR-128b regulates the formation of fear-extinction memory. Nat Neurosci 14: $1115-1117$.

Luhur A, Chawla G, Wu YC, Li J, Sokol NS. 2014. Drosha-independent DGCR8/Pasha pathway regulates neuronal morphogenesis. Proc Natl Acad Sci 111: 1421-1426.

Luikart BW, Bensen AL, Washburn EK, Perederiy JV, Su KG, Li Y, Kernie SG, Parada LF, Westbrook GL. 2011. miR-132 mediates the integration of newborn neurons into the adult dentate gyrus. PLoS One 6: e19077.

Lukiw WJ. 2007. Micro-RNA speciation in fetal, adult and Alzheimer's disease hippocampus. Neuroreport 18: 297-300.

Magill ST, Cambronne XA, Luikart BW, Lioy DT, Leighton BH, Westbrook GL, Mandel G, Goodman RH. 2010. microRNA-132 regulates dendritic growth and arborization of newborn neurons in the adult hippocampus. Proc Natl Acad Sci 107: 20382-20387.

Marler KJ, Suetterlin P, Dopplapudi A, Rubikaite A, Adnan J, Maiorano NA, Lowe AS, Thompson ID, Pathania M, Bordey A, et al. 2014. BDNF promotes axon branching of retinal ganglion cells via miRNA-132 and p250GAP. J Neurosci 34: 969-979.

Mayford M, Bach ME, Huang YY, Wang L, Hawkins RD, Kandel ER. 1996. Control of memory formation through regulated expression of a CaMKII transgene. Science 274: 1678-1683.

Mellios N, Sugihara H, Castro J, Banerjee A, Le C, Kumar A, Crawford B, Strathmann J, Tropea D, Levine SS, et al. 2011. miR-132, an experience-dependent microRNA, is essential for visual cortex plasticity. Nat Neurosci 14: $1240-1242$.

Miller BH, Zeier Z, Xi L, Lanz TA, Deng S, Strathmann J, Willoughby D, Kenny PJ, Elsworth JD, Lawrence MS, et al. 2012. MicroRNA-132 dysregulation in schizophrenia has implications for both neurodevelopment and adult brain function. Proc Natl Acad Sci 109: 3125-3130.

Mishima T, Fujiwara T, Kofuji T, Akagawa K. 2012. Impairment of catecholamine systems during induction of long-term potentiation at hippocampal CA1 synapses in HPC-1/syntaxin 1A knock-out mice. J Neurosci 32: 381-389.

Mitchell SJ, Ryan TA. 2005. Munc18-dependent regulation of synaptic vesicle exocytosis by syntaxin-1A in hippocampal neurons. Neuropharmacology 48: 372-380.

Mizuno M, Yamada K, Maekawa N, Saito K, Seishima M, Nabeshima T. 2002. CREB phosphorylation as a molecular marker of memory processing in the hippocampus for spatial learning. Behav Brain Res 133: $135-141$.

Nakamura K, Anitha A, Yamada K, Tsujii M, Iwayama Y, Hattori E, Toyota T, Suda S, Takei N, Iwata Y, et al. 2008. Genetic and expression analyses reveal elevated expression of syntaxin 1A (STX1A) in high functioning autism. Int J Neuropsychopharmacol 11: 1073-1084.

Nudelman AS, DiRocco DP, Lambert TJ, Garelick MG, Le J, Nathanson NM, Storm DR. 2010. Neuronal activity rapidly induces transcription of the CREB-regulated microRNA-132, in vivo. Hippocampus 20: 492-498.

Nuovo GJ. 2010. In situ detection of microRNAs in paraffin embedded, formalin fixed tissues and the co-localization of their putative targets. Methods 52: 307-315.

Obernosterer G, Martinez J, Alenius M. 2007. Locked nucleic acid-based in situ detection of microRNAs in mouse tissue sections. Nat Protoc 2: $1508-1514$.

Oulas A, Karathanasis N, Louloupi A, Pavlopoulos GA, Poirazi P, Kalantidis K, Iliopoulos I. 2015. Prediction of miRNA Targets. Methods Mol Biol 1269: 207-229.

Packer AN, Xing Y, Harper SQ, Jones L, Davidson BL. 2008. The bifunctional microRNA miR-9/miR-9* regulates REST and CoREST and is downregulated in Huntington's disease. J Neurosci 28: 14341-14346.

Parras CM, Galli R, Britz O, Soares S, Galichet C, Battiste J, Johnson JE, Nakafuku M, Vescovi A, Guillemot F. 2004. Mash1 specifies neurons and oligodendrocytes in the postnatal brain. EMBO J 23: $4495-4505$.

Porte Y, Buhot MC, Mons NE. 2008. Spatial memory in the Morris water maze and activation of cyclic AMP response element-binding (CREB) protein within the mouse hippocampus. Learn Mem 15: 885-894.

Remenyi J, van den Bosch MW, Palygin O, Mistry RB, McKenzie C, Macdonald A, Hutvagner G, Arthur JS, Frenguelli BG, Pankratov Y. 2013. miR-132/-212 knockout mice reveal roles for these miRNAs in regulating cortical synaptic transmission and plasticity. PLoS One 8: e62509.

Ruiz-Montasell B, Aguado F, Majó G, Chapman ER, Canals JM, Marsal J, Blasi J. 1996. Differential distribution of syntaxin isoforms 1A and 1B in the rat central nervous system. Eur J Neurosci 8: 2544-2552.

Sánchez-Mora C, Cormand B, Ramos-Quiroga JA, Hervás A, Bosch R, Palomar G, Nogueira M, Gómez-Barros N, Richarte V, Corrales M, et al. 2013. Evaluation of common variants in 16 genes involved in the regulation of neurotransmitter release in ADHD. Eur Neuropsychopharmacol 23: 426-435.

Schratt GM, Tuebing F, Nigh EA, Kane CG, Sabatini ME, Kiebler M, Greenberg ME. 2006. A brain-specific microRNA regulates dendritic spine development. Nature 439: 283-289.

Scott HL, Tamagnini F, Narduzzo KE, Howarth JL, Lee YB, Wong LF, Brown MW, Warburton EC, Bashir ZI, Uney JB. 2012. MicroRNA-132 regulates recognition memory and synaptic plasticity in the perirhinal cortex. Eur J Neurosci 36: 2941-2948.

Shaltiel G, Hanan M, Wolf Y, Barbash S, Kovalev E, Shoham S, Soreq H. 2013. Hippocampal microRNA-132 mediates stress-inducible cognitive deficits through its acetylcholinesterase target. Brain Struct Funct 218: $59-72$.

Sheinerman KS, Tsivinsky VG, Abdullah L, Crawford F, Umansky SR. 2013. Plasma microRNA biomarkers for detection of mild cognitive impairment: biomarker validation study. Aging (Albany NY) 5: 925-938.

Söllner T, Bennett MK, Whiteheart SW, Scheller RH, Rothman JE. 1993a. A protein assembly-disassembly pathway in vitro that may correspond to sequential steps of synaptic vesicle docking, activation, and fusion. Cell 75: 409-418.

Söllner T, Whiteheart SW, Brunner M, Erdjument-Bromage H, Geromanos S, Tempst P, Rothman JE. 1993b. SNAP receptors implicated in vesicle targeting and fusion. Nature 362: $318-324$.

Soriano P. 1999. Generalized lacZ expression with the ROSA26 Cre reporter strain. Nat Genet 21: 70-71.

Sun G, Li H, Rossi JJ. 2010. Sequence context outside the target region influences the effectiveness of miR-223 target sites in the RhoB $3^{\prime} \mathrm{UTR}$. Nucleic Acids Res 38: 239-252.

Sunyer B, Patil S, Höger H, Lubec G. 2007. Barnes maze, a useful task to assess spatial reference memory in the mice. Protoc Exch. doi: 10.1038/ nprot.2007.390.

Swayne LA, Chen L, Hameed S, Barr W, Charlesworth E, Colicos MA, Zamponi GW, Braun JE. 2005. Crosstalk between huntingtin and syntaxin $1 \mathrm{~A}$ regulates N-type calcium channels. Mol Cell Neurosci 30: $339-351$

Szeto CY, Lin CH, Choi SC, Yip TT, Ngan RK, Tsao GS, Li Lung M. 2014. Integrated mRNA and microRNA transcriptome sequencing characterizes sequence variants and mRNA-microRNA regulatory network in nasopharyngeal carcinoma model systems. FEBS Open Bio 4: $128-140$.

Tognini P, Pizzorusso T. 2012. MicroRNA212/132 family: molecular transducer of neuronal function and plasticity. Int J Biochem Cell Biol 44: $6-10$.

Tognini P, Putignano E, Coatti A, Pizzorusso T. 2011. Experience-dependent expression of miR-132 regulates ocular dominance plasticity. Nat Neurosci 14: 1237-1239. 
Tsien JZ, Chen DF, Gerber D, Tom C, Mercer E, Anderson DJ, Mayford M, Kandel ER, Tonegawa S. 1996. Subregion and cell type-restricted gene knockout in mouse brain. Cell 87: 1327-1338.

van Spronsen M, van Battum EY, Kuijpers M, Vangoor VR, Rietman ML, Pothof J, Gumy LF, van Ijcken WF, Akhmanova A, Pasterkamp RJ, et al. 2013. Developmental and activity-dependent miRNA expression profiling in primary hippocampal neuron cultures. PLoS One 8: e74907.

Vasconcelos FF, Castro DS. 2014. Transcriptional control of vertebrate neurogenesis by the proneural factor Ascl1. Front Cell Neurosci 8: 412.

Viosca J, Malleret G, Bourtchouladze R, Benito E, Vronskava S, Kandel ER, Barco A. 2009. Chronic enhancement of CREB activity in the hippocampus interferes with the retrieval of spatial information. Learn Mem 16: 198-209.

Vo N, Klein ME, Varlamova O, Keller DM, Yamamoto T, Goodman RH, Impey S. 2005. A cAMP-response element binding protein-induced microRNA regulates neuronal morphogenesis. Proc Natl Acad Sci 102: 16426-16431.

Wada R, Akiyama Y, Hashimoto Y, Fukamachi H, Yuasa Y. 2010. miR-212 is downregulated and suppresses methyl-CpG-binding protein MeCP2 in human gastric cancer. Int J Cancer 127: 1106-1114.

Wanet A, Tacheny A, Arnould T, Renard P. 2012. miR-212/132 expression and functions: within and beyond the neuronal compartment. Nucleic Acids Res 40: 4742-4753.
Wang WX, Huang Q, Hu Y, Stromberg AJ, Nelson PT. 2011. Patterns of microRNA expression in normal and early Alzheimer's disease human temporal cortex: white matter versus gray matter. Acta Neuropathol 121: $193-205$.

Wang RY, Phang RZ, Hsu PH, Wang WH, Huang HT, Liu IY. 2013. In vivo knockdown of hippocampal miR-132 expression impairs memory acquisition of trace fear conditioning. Hippocampus 23: $625-633$.

Wayman GA, Davare M, Ando H, Fortin D, Varlamova O, Cheng HY, Marks D, Obrietan K, Soderling TR, Goodman RH, et al. 2008. An activity-regulated microRNA controls dendritic plasticity by down-regulating p250GAP. Proc Natl Acad Sci 105: 9093-9098.

Wehner JM, Radcliffe RA. 2004. Cued and contextual fear conditioning in mice. Curr Protoc Neurosci Chapter 8: Unit 8.5C.

Yang JH, Qu LH. 2013. Discovery of microRNA regulatory networks by integrating multidimensional high-throughput data. Adv Exp Med Biol 774: 251-266.

Received July 14, 2015; accepted in revised form November 18, 2015. 


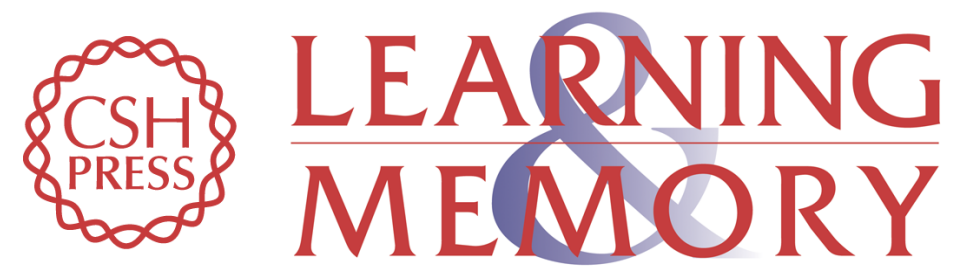

\section{Targeted deletion of miR-132/-212 impairs memory and alters the hippocampal transcriptome}

Katelin F. Hansen, Kensuke Sakamoto, Sydney Aten, et al.

Learn. Mem. 2016, 23:

Access the most recent version at doi:10.1101/lm.039578.115

\section{Supplemental http://learnmem.cshlp.org/content/suppl/2016/01/06/23.2.61.DC1 Material}

References This article cites 95 articles, 26 of which can be accessed free at: http://learnmem.cshlp.org/content/23/2/61.full.html\#ref-list-1

Creative This article is distributed exclusively by Cold Spring Harbor Laboratory Press for the Commons first 12 months after the full-issue publication date (see

License http://learnmem.cshlp.org/site/misc/terms.xhtml). After 12 months, it is available under a Creative Commons License (Attribution-NonCommercial 4.0 International), as described at http://creativecommons.org/licenses/by-nc/4.0/.

Email Alerting Receive free email alerts when new articles cite this article - sign up in the box at the Service top right corner of the article or click here. 